\title{
Impact of COVID 19 on the provision of services by public administration
}

\author{
Maria Zilincikova ${ }^{1, *}$, and Jana Stofkova ${ }^{2}$ \\ ${ }^{1}$ University of Zilina, Faculty of Operation and Economics of Transport and Communications, \\ Department of Communications, Univerzitna 1, 01026 Zilina, Slovakia \\ ${ }^{2}$ University of Zilina, Faculty of Operation and Economics of Transport and Communications, \\ Department of Economics, Univerzitna 1, 01026 Zilina, Slovakia
}

\begin{abstract}
.
Research background: The digitization of public administration processes has helped the functioning of the public sector at a time when the health of citizens is threatened by the virus. The economic sustainability of public administration has its place in government programs as an important means of modernizing, supporting, and optimizing the functioning of the public sector, improving public services. It focuses on a sustainable state in an emergency, or in times of crisis.

Purpose of the article: The aim of the paper is to analyze and compare electronic services provided by public administration to citizens, businesses before and after the corona virus. The above analysis was supplemented by a questionnaire survey among citizens, entrepreneurs of the Slovak Republic focusing on the satisfaction of electronic public administration services at the time of the corona virus.

Methods: The article applied the analysis and comparison of the state of provided electronic services before and after the corona virus. Prediction of future development was determined based on available data, by ex-ante analysis using the method of simple moving averages. An additional method of research was primary research satisfaction.

Findings \& Value added: An important milestone in the time of the coronary virus pandemic is the optimization of systems, services, and the strengthening of intervention capacities for emergency management. The findings presented in the paper point to changes related to the economic development of the state economy, changes in employment in the labor market and planned measures to rehabilitate the damage caused by COVID 19.
\end{abstract}

Keywords: corona virus; digital transformation; informatization; technologies; public administration

JEL Classification: L86; O14; O32; O38; H89

*Corresponding author: maria.zilincikova@,fpedas.uniza.sk 


\section{Introduction}

The COVID-19 pandemic crossed political, jurisdictional, but also state borders. Responding to such a cross-border global coronary crisis requires the involvement of government agencies at all levels, as well as at a broad level of a range of organizations from non-profit to private sectors. [1] The situation in the Slovak Republic began to change dramatically. Concerns about the corona crisis have become a reality. Despite the efforts of the crisis staff, the government documented the first deaths and therefore had to take emergency measures. Infection clinics have experienced an influx of infected patients, many times staff have been at risk and infected from irresponsible patients who have not followed hygiene measures or have met a positively infected person. The government subsequently declared a state of emergency. Epidemiologists have urged people to stay in domestic isolation and not go anywhere. This was the only way to prevent the uncontrolled spread of COVID-19. Apart from pharmacies and food, all operations such as cafes, cinemas and fitness centres were closed. They were closed until further notice. Strict hygienic measures were ordered by the state power to prevent the spread of COVID-19 to other people, and all the surrounding borders of Slovakia were gradually closed.

After a period of temporary black-out of the country and stabilization of infected patients, introduction of mandatory quarantine, measures were relaxed and businesses and operations began to open. Mass events have been reduced and the Public Health Office of the Slovak Republic is constantly monitoring the current situation and subsequently individual measures against the COVID-19 infection are being adapted and changed. From an epidemiological point of view, much of the media rate Slovakia as the most successful European country in the fight against the spread of coronavirus disease 2019 (COVID-19). Such excellent results were achieved in a truly specific way. [2] Disease COVID-19 belongs to the family of viruses that are found in animals. Its origins come from Wuhan, a city of 11 million people and a large industrial educational and scientific base in China. [3]

\subsection{Public administration and digital economy in the Slovak Republic}

Public administration can be seen in a broader sense as a service to citizens, performed by several authorities in the public interest. Public services must therefore fulfil the condition of indivisibility and non-exclusion from consumption. In this understanding of public administration, it is appropriate to respect and analyse several specific characteristics. Based on the typology of services, services provided by public administration organizations are among the services provided to a large number of customers, they are performed without significant technical support and with a relatively exceptional interaction between the service provider and the customer. [4]

The digital economy, as a new direction in the industry, has also brought new types of businesses to market, business models that were previously unthinkable, regular video conferencing that allows the whole world to connect at any place and time. [5] Innovations are ongoing, they are automatically incorporated into all areas. Generations born after 1990 cannot imagine life without ICT. The EU's digital single market aims to strengthen Europe's position as a world leader in the digital economy. The new direction of the knowledge society, and that is the digital economy, is moving in this direction. A new sector of the national economics, highlights information and communication technologies that enable a wide portfolio of products and services. Products and services supported by ICT (information and communication technologies) also enter areas that have hitherto operated on the principle of the human factor or through the involvement of machine capital. [6] 
E-Government is a component of the digital economics, it is currently implementing new technologies and has become an integral part of the public sector. The United Nations considers the role of e-Government to be "to improve relations between the citizen and the public sector by providing affordable and efficient services as well as providing new information and knowledge". [7] We are governed by the Act on the Electronic Form of the Exercise of Powers of Public Authorities and on Amendments to Certain Acts (Act on eGovernment) 305/2013 effective from 01.07.2020. These objectives of the exercise of public power are electronically ensured by public authorities, within the scope of their competence according to the law, the creation and operation of access points, common modules, and agenda systems. Access points are communication interfaces through which it is possible to perform electronic communication with citizens and businesses. [8] We understand them as the central portal of public administration, specialized portals, integrated service points, central contact centre.

\subsection{Pandemic plan and its impacts on public administration in the Slovak Republic}

The analysis of the impact of COVID-19 on the provision of services by the public administration examined the impact on the public administration and the pandemic plan. The purpose of the Pandemic Plan for a Pandemic in the Slovak Republic is to ensure the readiness of the Slovak Republic for a pandemic of acute respiratory diseases, elimination of health and economic burden on the population, economy and public life, determination of tasks of state administration bodies, local authorities and professional bodies. perform activities in connection with ensuring the protection of public health in preparation for a pandemic and at the time of a declared pandemic. It was established on 11 August 2020. It was approved by the Pandemic Commission of the Government of the Slovak Republic pursuant to Article 3 letter a) of the Statute of the Pandemic Commission of the Government of the Slovak Republic, prepared by the Public Health Office of the Slovak Republic. [9] The Centres for Disease Control and Prevention (CDC) characterize social vulnerability as "the resilience of communities that are confronted with external pressures on human health, such as natural or man-made disasters or outbreaks of disease." [10] The Pandemic Commission of the Government of the Slovak Republic is characterized as a multi-ministerial, coordinating, consulting, expert and advisory body of the Government of the Slovak Republic established with the intention of proposing measures to protect lives and health and reduce the economic burden on the population in order to maintain the necessary economy and public life.

The Operational Centre of the Pandemic Commission of the Government of the Slovak Republic is established at the Ministry of Health of the Slovak Republic as a temporary professional coordinating body of the Pandemic Commission of the Government of the Slovak Republic to provide cooperation in organizing pandemic risk reduction procedures in cooperation with end. According to the instructions of the Chairman of the Pandemic Commission of the Government of the Slovak Republic, he will prepare the information and documents necessary for the meeting of the Pandemic Commission of the Government of the Slovak Republic. The Operational Centre of the Pandemic Commission of the Government of the Slovak Republic is established for a period during a pandemic. An endemic occurrence of a disease is a commonly occurring disease normally associated with a particular population in a particular area. A respiratory disease pandemic is a condition in which the conditions for pandemic spread are met confirmation of human-to-human transmission of the new virus, its transmission in the population, and its occurrence recorded on at least two continents. The pandemic is declared by the World Health Organization. [11] 


\section{Methodology}

The study examines the association between COVID-19 and electronic services provided by public administration before and after the corona. For this purpose, data on COVID-19 from the World Health Organization (WHO) and data available on the portal of the Public Health Office of the Slovak Republic were collected. The first patient was reported in the Slovak Republic on March 6, 2020, but the data are processed for the period March 6, 2020 to September 23, 2020. Using an ex-ante analysis of current data, we estimated the prediction of future development using the simple moving averages method. A complementary method of research was a questionnaire survey among citizens, entrepreneurs of the Slovak Republic focused on the satisfaction of electronic services of public administration at the time of the occurrence of the corona virus.

The aim of the article was to define the impact of the coronary crisis on the provision of e-Government services. Subsequently, a primary research focused on the satisfaction of users of electronic public administration services was carried out, which will lead to an increase in the competitiveness of the Slovak public administration vis-à-vis other EU countries in today's globalized world. The sample size is calculated from the total number of users of electronic services involved in the survey - 196. Given the size of the base sample, we used the calculation of the size of the base files using the following formula:

$$
\begin{gathered}
n \geq t_{1-\frac{\alpha}{2}}^{2} * \frac{\sigma^{2}}{\Delta^{2}} \\
\sigma=\sqrt{p^{*}(1-p)}
\end{gathered}
$$

where:

$\mathrm{n}$ - the minimum sample size (minimum number of respondents),

$\mathrm{t} 1-\alpha / 2$ - reliability of estimation, critical value determined from tables,

$\sigma 2$ - the variance calculated from the standard deviation,

$\Delta$ - the maximum allowable margin of error,

$\mathrm{N}$ - base file size.

Then we put the values into the formula:

$\mathrm{p}=0,5$

$\mathrm{t} 1-\alpha / 2=1,96$

$$
\begin{gathered}
\sigma 2=>\sigma=\sqrt{p^{*(1-p)}}=\sqrt{0,5 *(1-0,5)}=0,5 \\
n \geq \frac{1,96^{2} \cdot 0,5^{2}}{0,07^{2}} \geq 196
\end{gathered}
$$

The above used formula is suitable for binomial distribution and in the case of alternative and multinomial distribution it is necessary to modify this formula. A questionnaire survey was conducted on the examined sample. After substituting the values into the formula for calculating a large sample of the population. We found that with $95 \%$ reliability and a specified maximum permissible error deviation of $\pm 7 \%$. The minimum sample size was calculated by 196 respondents. It can be stated that the requirement to meet the implementation of the minimum sample size has been met. Other methods used in this article were the induction and deduction method. The above methods were used to evaluate the primary research. The last step was to use the synthesis method. The individual 
conclusions were made as described above. The sample of respondents was purposefully selected to be citizens who use electronic services as citizens, but also as entrepreneurs.

\section{Analysis of the services}

An important milestone in the time of the coronary virus pandemic is the optimization of systems, services, and the strengthening of emergency management interventions. The findings presented in the paper point to changes in the economic development of the state economy, changes in employment in the labour market and planned measures to repair the damage caused by COVID 19. Governance processes are not only expected to ensure coordination of basic needs such as food, medicine, social safety net, but will also put in place high-quality public health systems during this pandemic. Fig. 1 shows the overall development of the COVID-19 pandemic in the Slovak Republic. [12]

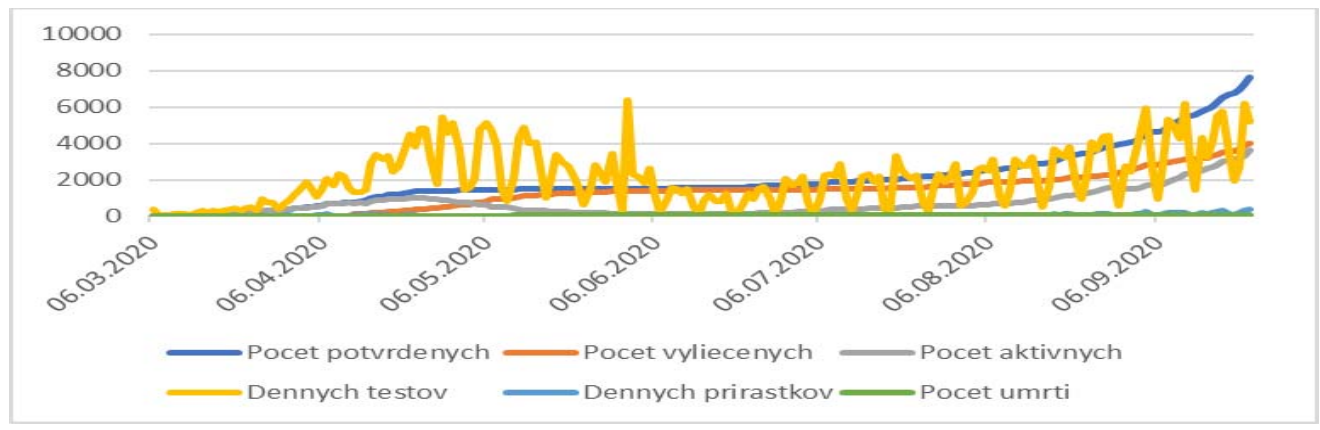

Fig. 1. Overall development of the situation with COVID-19 in Slovakia. [11]

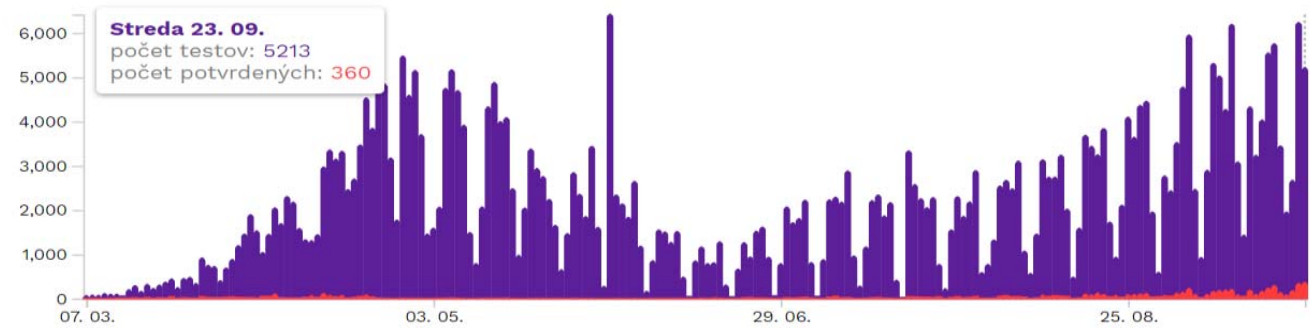

Fig. 2. Daily number of new tests and confirmed COVID-19 patients for the period from 6 March 2020 to 23 September 2020. [13]

Fig. 2 is shown in two colours, the number of tests performed in the period from March 6, 2020 to September 23, 2020 is shown in blue, and the number of confirmed patients with COVID-19 is indicated in red. The expected development points to the second wave of the pandemic. The rising nature of the pandemic is currently expected. Current data show that one positive patient with COVID-19 infects one other person from his surroundings. The average scenario was examined, which predicts the values of the infection of the population of the Slovak Republic for the near future. It is shown in Fig. 3 and points to an increasing trend of cases (red arrow), specifically for the period October - November 2020.

During this period, governments around the world have benefited from a wide range of communication channels to which citizens can be challenged and thus contribute to limiting the spread of the virus and to protecting and supporting vulnerable people. [14] The effects of COVID-19 for this population are inextricably linked to areas of systemic oppression and partial restricted freedom of citizens, increasing health inequalities, segregation, overall 
health, and food insecurity when COVID-19 affects public and medical prosecutors. this under-representation in government and the medical profession and, finally, surface inequalities in participatory democracy. $[15,16]$

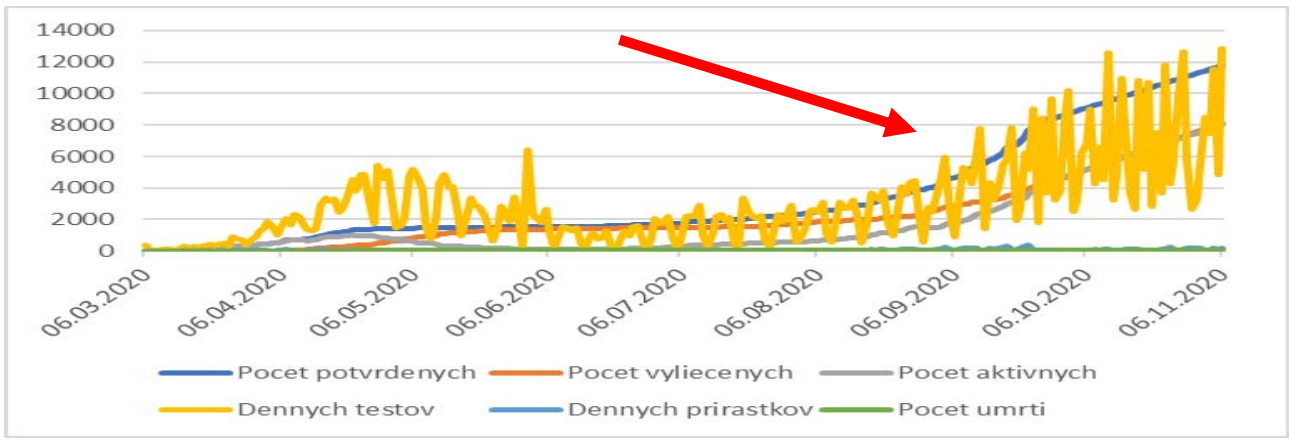

Fig. 3. Prediction of the development of the daily number of new tests confirmed by COVID-19 patients in the period from 6 March 2020 to 6 November 2020. [17]

Governments around the world are trying to come to terms with how they can respond as effectively as possible to ongoing events. They are overwhelmed by competing expert opinions on this situation. Public value trade-offs and capacity constraints are good keys to finding a solution. Administrative capacity is a decisive factor in deciding whether these circumstances give rise to unprecedented situations of resilience and optimism or despair, and it will then be clear whether confidence in the government will increase or decrease. [18] The WHO has published three reports to the UN General Assembly that a pandemic must motivate us to redouble our efforts to achieve the goals of sustainable development. Fair access to diagnostics, therapeutics and vaccines must be ensured. [19]

\subsection{New and expanded public administration services thanks to coronavirus}

Digital public service delivery has improved in Europe over the last two years. This is the result of a reference report on electronic government (eGovernment) published today by the European Commission. Evaluation criteria include transparency of public online services, user accessibility and cross-border mobility. European pioneers in the eGovernment zone include Malta (overall score 97\%), Estonia (92\%), Austria (87\%) and Latvia (87\%). These countries scored highest in all four benchmarks at the highest level, closely followed by Denmark (84\%), Lithuania (83\%) and Finland (83\%). [18] The Public Health Office of the Slovak Republic has created a special page COVID-19, where citizens can find all important information about this disease, current statistics, disease development, call centres of regional public health offices in the Slovak Republic, leaflets, information materials and various other useful information. Everything is accessible on the website www.uvzsr.sk. Digital health interventions provide high-impact, inexpensive, readily available, and scalable interventions for large patient populations that address time and resource constraints. [20]

Self-governing regions in the Slovak Republic recommend to all their facilities to increase security measures in connection with Coronavirus. Disinfectants were added to school facilities, as well as increased preventive hygiene measures in social services facilities and in the founding powers of self-governing regions. Disinfection of city and suburban buses (air conditioning and heating) has increased. Mass events and weddings are limited to a minimum of participants. The Ministry of Education, Science, Research and Sports has introduced a new platform COVID - a school traffic light to obtain data from school principals and school facilities on the development of the epidemiological situation. 
This information will help departmental professionals to respond to the needs of schools and to update anti-epidemic measures and recommendations.

It is worth mentioning that new crisis packages have been introduced for companies, SEP (self-employed person) and employees, social benefits such as pandemic nursing care, etc. All the above subsidies and state contributions can be requested electronically. Assistance for companies and SEP includes subsidies to pay rent, a contribution to the employee's salary, which arose as a reaction of the Slovak government to mitigate the negative economic consequences as result of emergency measures taken to prevent the consequences of the spread of dangerous infectious human disease COVID-19.

If SEP's sales fell by at least $20 \%$, they could apply for a flat-rate contribution to compensate for the loss of income from self-employment. SEP and single-person s. r. o., who had no income until March 13, 2020, could apply for a contribution to compensate for the loss of income from gainful activity. In the tax and customs area, entrepreneurs could use the deferral of income tax advances, settlement of the positive difference in income tax advances FO and PO until the filing of income tax return, non-payment of income tax advances to natural and legal persons, postponement of legal deadlines in income tax, deferral of tax executions, refund of tax overpayments, deduction of tax loss (for the years 2015 to 2018), non-payment of advances for motor vehicle tax, application of a preferential rate of excise duty. A measure in the form of remission of levies by employers and SEP was introduced too. It was possible to request the waiver of levies electronically by a solemn declaration, which was sent to the relevant branch of the Social Insurance Agency. The provision of financial assistance by the Ministry of Finance of the Slovak Republic for micro, small and medium-sized enterprises took the form of loan guarantees and interest rate subsidies on loans. Entrepreneurs could use this help. It was possible to apply for soft loans from the Slovak Guarantee and Development Bank (SZRB), a special project was launched to help entrepreneurs with the help of Eximbanka (EXIM). [21]

Today, the Financial Administration already manages its offices in such a way that tax subjects who are in any way affected by the crisis caused by the spread of coronavirus are as accommodating as possible - for example by extending deadlines for sending documents by agreeing to waiver requests, etc. Mutual communication with the relevant financial administration is important. A special website www.pomahameludom.sk was created for first aid to employees, entrepreneurs, and sole traders. The Ministry of Labour, Social Affairs and Family of the Slovak Republic has also added the section "Coronavirus - labour and social area - important information" to its website employment.gov.sk. On the Ministry's website, it is possible to find electronic services, forms and applications supplemented by forms relating to the pandemic situation with COVID-19. The National Cyber Security Centre (NCKB) SK-CERT has published warnings that citizens, employees, companies, and public authorities should follow. Specifically, a warning to public authorities against underestimating the solution to cyber security in an emergency. [22]

\subsection{Satisfaction of users of electronic services}

The sample of 196 respondents was purposefully selected to be citizens who also use electronic services as entrepreneurs. Respondents' satisfaction was diverse. Primary research examined satisfaction before and after coronary crisis. The data obtained shown in the graphs of Fig. 4 and Fig. 5 below.

1. The above graphs express the satisfaction of the respondents with electronic public administration services. The situation before the corona crisis was perceived by respondents as a state of insufficient electronic services compared to EU countries. As many as $68 \%$ of respondents indicated that they knew electronic public administration abroad and expressed their dissatisfaction with the non-functioning e-Government in Slovakia. They stated that 
before the coronary crisis they filled in the forms electronically, but in most cases, there was a problem in signing the document, or in the failure of the financial report.

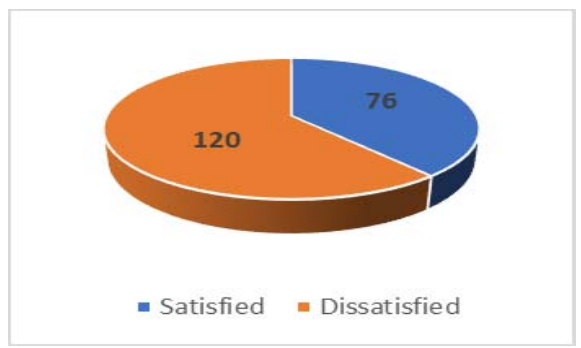

Fig. 4. Satisfaction of respondents with electronic services of public administration before the coronary crisis.

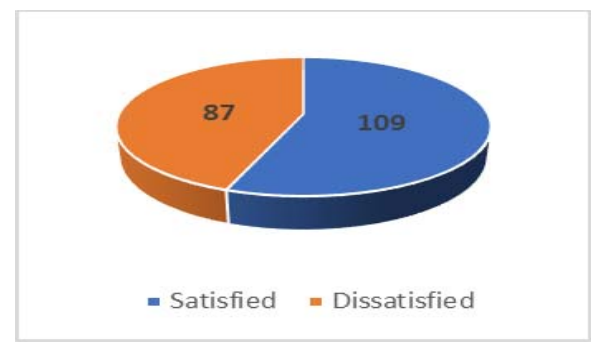

Fig. 5. Satisfaction of respondents with electronic services of public administration after the coronary crisis.

They also reported dissatisfaction with the Social Insurance Agency system and the submission of monthly reports for employees. As many as $89 \%$ said that it had happened to them that the recording of the report had been interrupted and they had to repeat the recording process. At health insurance companies, $88 \%$ were satisfied with the electronic services of VŠZP as citizens and as entrepreneurs. According to the respondents, the Union provides average electronic services to entrepreneurs and expressed $50 \%$ satisfaction and $50 \%$ dissatisfaction. The extreme value came out when using the web portal of the health insurance company Dôvera, where only $5 \%$ of respondents were satisfied, i.e.. most active users of the portal were dissatisfied. When evaluating the satisfaction of the web portals of individual ministries of the Slovak Republic, similar values were published. The vast majority were not satisfied with the web portals and they lacked the missing information they were looking for but did not find. The financial report was similarly similar, with $65 \%$ of respondents saying that they were not satisfied with the frequent outages of the financial administration web portal, the information on the financial administration website is a lot and is confusing.

2. When comparing the state of satisfaction of respondents with electronic services after the coronary crisis, it is possible to point to greater satisfaction. Before the coronary crisis, 120 respondents were dissatisfied $(61 \%), 76$ respondents were satisfied (39\%). In contrast, the situation after the coronary crisis shows the fact that public administration institutions were more involved in digital transformation and digitization of documents, which brought satisfaction $(109(56 \%))$ and dissatisfied 87 (44\%) respondents. This fact has shown that users of electronic services are noticing changes in the e-Government system and are in favour of greater electronic public administration. They also indicated a preference that they would welcome the use of a mobile application in the future to send applications, forms, and overall communication with the public administration in a simpler and more accessible form. The coronary crisis shows the fact that it is possible to move eGovernment in the Slovak Republic to a higher level and thus cope with EU countries, which are at the forefront of using e-Government for their citizens and entrepreneurs.

\section{Conclusion}

Given that COVID-19 is spreading rapidly around the world, causing the widespread socio-economic disruption that has been the greatest threat since World War II. Researchers, stakeholders, government, and society are actively looking for ways to reduce the rate of infection until it is cured or to establish a vaccination course. [23] 
Global digitization and informatization is also reflected in the provision of electronic services to citizens and businesses. Government regulations have limited office hours by order of the Government of the Slovak Republic and provide services to citizens, as much as possible in electronic form. Healthcare makes extensive use of platforms based on software for doctors, e-prescriptions are being issued, applications from health insurance companies are being used, etc. Transport includes software support and programs for professional drivers, dispatchers who plan the most efficient routes, thus reducing the company's costs as well as reducing emissions from trucks, cars. Overall, in the current situation, a restriction on social contact between Slovak citizens has been introduced. Although the Financial Report has a lot of information on its website, there is too much in confusing sections. When creating electronic documents and sending tax returns, the colour coding of individual sections of current and past forms is inappropriate. The positive is that it is possible to use an electronic signature when signing electronic documents using a citizen's card of a Slovak citizen (eID card).

In summary, it can be stated that all ministries of the Slovak Republic have added links to electronic services, forms, and applications to their websites. Similarly, self-governing regions, cities, municipalities, the social insurance company, health insurance companies and the financial administration approached the situation with COVID-19. The digital transformation of the Slovak Republic has helped to better manage the crisis situation and the overall coronary crisis, which still persists and the damage caused in this period will be reflected in the economic, economical and health aspects of our country.

The acknowledgement - This paper was supported by project VEGA 1/0518/19.

\section{References}

1. Hu, Q., Zhang, H., Kapucu, N., Chen, W. (2020). Hybrid coordination for coping with the medical surge from the covid-19 pandemic: Paired-assistance programs in China. Public Administration Review, 80(5), 895-901.

2. Nemec, J. (2020). Government transition in the time of the COVID-19 crisis: Slovak case. International Journal of Public Leadership, Vol. ahead-of-print No. ahead-ofprint.

3. Usman, M., Ali, Y., Riaz, A., Riaz, A., Zubair, A. (2020). Economic perspective of coronavirus (COVID-19). Journal of Public Affairs, e2252.

4. Hamalova, M., Belajova, A., Gecikova, I., Papcunova, V. (2014). Teória, riadenie a organizácia verejnej správy [Theory, management and organization of public administration]. Bratislava: Wolters Kluwer.

5. Stofkova, Z., Hraskova, D. (2017). Digital skills in period of digital economy. In: Petranova, D., Rybansky, R., Mendelova, D. (Eds.). Marketing Identity, International Scientific Conference on Marketing Identity, (pp. 417-425). Trnava: Univ Ss Cyril \& Methodius Trnava.

6. OECD. (2020) Brusel: URL (2019, October 23). The digital economy. http://www.oecd.org/daf/competition/The-Digital-Economy-2012.pdf?fbclid=Iw AR0UEcijWDA_pnPki0sDY8YkmUWBMH3FR09CMiJvXTStNvnzxhWk3WJ7dtQ/.

7. Stofkova, J., Stricek, I., Stofkova, K. (2015). Data analysis in quality management of the network enterprise. Engineering Science and Production Management, 273-278.

8. Gasova, K., Stofkova, K. (2017). E-Government as a quality improvement tool for citizens' services. Procedia Engineering, 192, pp. 225-230. 
9. Úrad verejného zdravotníctva Slovenskej republiky [Public Health Office of the Slovak Republic] (2020, August 11). Pandemický plán pre prípad pandémie v Slovenskej republike. Retrieve from: https://korona.gov.sk.

10. Gaynor, T. S., Wilson, M. E. (2020). Social vulnerability and equity: The disproportionate impact of COVID-19. Public Administration Review, 80(5), 832-838.

11. Zákon č. 179/2011 Z. z. o hospodárskej mobilizácii a o zmene a doplnení zákona č. 387/2002 Z. z. o riadení štátu v krízových situáciách mimo času vojny a vojnového stavu $v$ znení neskorších predpisov.

12. Schuster, C., Weitzman, L., Sass Mikkelsen, K., Meyer-Sahling, J., Bersch, K., Fukuyama, F., Kay, K. (2020). Responding to COVID-19 through surveys of public servants. Public Administration Review, 80(5), 792-796.

13. bot.media, s. r. o. (2020). Mapa.covid.chat. mapa.covid.chat. Retrieved from: URL (2020, September 23). Celkový vývoj. http://mapa.covid.chat/.

14. Steen, T., Brandsen, T. (2020). Co-production during and after the Covid-19 pandemic: will it last? Public Administration Review, COVID-19 Viewpoint Symposium, Viley online library.

15. Martin-Howard, S., Kyle Farmbry, J. D. (2020). Framing a needed discourse on health disparities and social inequities: Drawing lessons from a pandemic. Public Administration Review, COVID-19 Symposium, 80(5), 839-844.

16. Wright, J. E., Merritt, C. C. (2020). Social equity and covid-19: The case of African Americans. Public Administration Review, 80(5), 820-826.

17. Ministerstvo zdravotníctva Slovenskej republiky [Ministry of Health of the Slovak Republic] (2020, September 23). COVID-19. covid-19.nczisk.sk. Retrieved from: URL (2020, September 23). COVID-19. http:// https://covid-19.nczisk.sk/sk/.

18. van der Wal, Z. (2020). Being a public manager in times of crisis: The art of managing stakeholders, political masters, and collaborative networks. Public Administration Review, 80(5), 759-764.

19. World Health Organization. (2020, September 21). Who.int. Retrieved from: URL (2020, September 22). WHO Director-General's opening remarks at the media briefing on COVID-19 - 21 September 2020. http://fivethirtyeight.com/features/how-long-cana-spinoff-like-better-call-saul-last/.

20. European Commission. (2020, September 23). ec.europa.eu. Retrieved from: URL. (2020, September 23). eGovernment Benchmark 2020: eGovernment that works for the people. http:// https://ec.europa.eu/digital-single-market/

21. Hewitt, S., Sephton, R., Yeowell, G. (2020). The effectiveness of digital health interventions in the management of musculoskeletal conditions: Systematic literature review. Journal of Medical Internet Research, 22(6), e15617.

22. Národný bezpečnostný úrad [National Security Office] (2020). Retrieved from: URL (2020, August 17). Varovanie pre orgány verejnej moci pred podcenením riešenia kybernetickej bezpečnosti v čase núdzového stavu spôsobeného nákazou COVID-19. Retrieve from: https://www.sk-cert.sk

23. Adekola, H. A., Adekunle, I. A., Egberongbe, H. O., Onitilo, S. A., Abdullahi, I. N. (2020). Mathematical modeling for infectious viral disease: The COVID-19 perspective. Journal of Public Affairs, e2306. 